\title{
PERSEPSI PETANI TENTANG INOVASI BUDIDAYA PADI PANDANWANGI ORGANIK DI GABUNGAN PETANI ORGANIK (GPO) NYI SRI KECAMATAN CIANJUR KABUPATEN CIANJUR
}

\author{
Oleh : \\ Rosda Malia*) \\ Elis Sopia**) \\ lia.rosda@yahoo.com
}

\begin{abstract}
Abstrak
Dewasa ini, masyarakat mempunyai kesadaran dan lebih selektif dalam memilih sebuah produk terutama produk yang dikonsumsinya. Padi Pandanwangi merupakan beras varietas asli Cianjur. Salah satu yang membudidayakan adalah para petani yang tergabung dalam Gabungan Petani Organik Kecamatan Cianjur. Petani mempunyai pilihan tentang keputusannya untuk menanam padi dengan teknik dan inovasi yang dapat meningkatkan hasil produksi budidaya. Budidaya Padi Pandanwangi dengan metode budidaya organik menimbulkan persepsi yang berbeda-beda sehingga tidak semua petani menerapkan. Tujuan penelitian ini adalah mengetahui karakteristik petani, persepsi dan hubungan persepsi petani dengan karakteristik petani tentang inovasi budidaya Padi Pandanwangi organik di Gabungan Petani Organik (GPO) Nyi Sri Kecamatan Cianjur Kab. Cianjur. Hasil penelitian menunjukan: (1) petani Padi Pandanwangi organik Kecamatan Cianjur sebagian besar berada pada kelompok usia produktif, pendidikan di tingkat sekolah dasar, lahan milik sendiri dengan luas $<0,5$ ha dan memiliki pengalaman yang cukup dalam budidaya Padi Pandanwangi organik (2) persepsi petani tentang budidaya Padi Pandanwangi termasuk dalam kategori setuju tentang inovasi budidaya Padi Pandanwangi organik dengan skor 3,52. (3) hasil analisis korelasi Rank Spearman hubungan karakteristik petani dengan persepsi petani Padi Pandanwangi organik menunjukkan korelasi yang sangat rendah dengan nilai sebesar 0,052 .
\end{abstract}

Kata Kunci: Persepsi, Padi Pandanwangi Organik, Karakteristik.

\begin{abstract}
Today, people have an awareness and are more selective in choosing a product, especially the products they consume. Pandanwangi rice is Cianjur native variety rice. One of the cultivators is farmers who are members of the Association of Organic Farmers in Cianjur District. Farmers have a choice about their decision to plant rice with techniques and innovations that can increase aquaculture production. Pandanwangi Rice Cultivation with organic cultivation methods raises different perceptions so that not all farmers apply. The purpose of this study was to determine the characteristics, perceptions and relationships of farmers' perceptions with the characteristics of farmers about the innovation of organic Pandanwangi Rice cultivation in the Organic Farmers Association (GPO) Nyi Sri, Cianjur District, Kab. Cianjur. The results showed: (1) organic Pandanwangi Rice farmers in Cianjur sub-district were mostly in the productive age group, education at the elementary school level, self-owned land with an area of $<0.5$ ha and have sufficient experience in organic Pandanwangi Rice cultivation (2) farmers' perceptions of Pandanwangi Rice cultivation are included in the agreed category of organic Pandanwangi Rice cultivation innovation with a score of 3.52. (3) the results
\end{abstract}


of Spearman Rank correlation analysis of the characteristics of farmers with the perception of organic Pandanwangi Rice farmers showed a very low correlation with a value of 0.052 .

Keywords: Perception, Organic Pandanwangi rice, Characteristics.

*) Alumni Fakultas Sains Terapan UNSUR

**) Dosen Fakultas Sains Terapan UNSUR 


\section{PENDAHULUAN}

Dewasa ini, masyarakat Indonesia mempunyai kesadaran yang tinggi terhadap isu lingkungan dan kesehatan, terutama berhubungan dengan apa yang mereka makan. Semboyan back to nature, seolah telah menjadi trend di kalangan masyarakat menengah ke atas dan terus mewabah. Munculnya kesadaran masyarakat akan bahaya yang terkandung dalam makanan membuat masyarakat lebih selektif dalam memilih sebuah produk, terlebih untuk produk yang dikonsumsiny Sehingga di pasar banyak muncul berbagai produk pertanian organik seperti : sayur organik, buah organik, beras organik. Di negara-negara berkembang, seperti Indonesia, 4-5 tahun yang lalu pangan organik mulai populer.

Di seluruh dunia, pangan organic meningkat permintaannya. Daya saing usaha pertanian Indonesia akan meningkat jika mampu memenuhi permintaan dalam negeri serta meningkatkan ekspor. Hasil pertanian organic di Indonesia berupa : sayuran, padi, kopi, coklat, buah buahan, madu, minyak kelapa dan herbal. Sayuran dan padi diproduksi oleh petani skala kecil untuk pasar local (Damardjati, 2005 ).

Berbagai kebijakan telah dicanangkan oleh pemerintah sebagai upaya pengembangan pertanian organik di Indonesia. Salah satu program yang pernah dijalankan adalah program "Go Organic" pada Tahun 2001-2010. Menurut Budianta (2004) program ini bertujuan untuk meningkatkan ketahanan pangan dan kesejahteraan social. Pengembangan teknologi pertanian organic, pembentukan kelompok tani dan strategi pemasaran produk organic menjadi kegiatan program tersebut. Harapannya pada Tahun 2010 Indonesia menjadi produsen produk organik yang dapat bersaing di tingkat dunia dan terciptanya kesempatan untuk meningkatkan pendapatan petani (Hidayat dan Lesmana, 2011). Pertanian organik belum sepenuhnya memasyarakat, baik oleh petani sendiri maupun oleh pemerintah. Walaupun perkembangannya kurang memuaskan namun gerakan Go Organic 2010 yang telah dicanangkan Kementerian Pertanian memberikan hasil yang positif terhadap para petani. Petani mengatakan pendapatannya meningkat sekitar 20-30 \% setelah mereka menerapkan sistem pertanian organic (Mayrowani et al., 2010). (40\%)

Salah satu daerah penghasil produk pangan organik di Jawa Barat adalah Kabupaten Cianjur. Salah satu yang menjadi varietas unggul dan merupakan produk asli dari Indonesia adalah beras beraroma pandan yang diberi nama Pandanwangi, beras varietas lokal asli Cianjur yang mempunyai banyak keunggulan baik itu dari aroma, bulir ataupun rasa nya. Padi Pandanwangi berbeda dengan jenis padi lainnya, pada proses pembudidayaan hingga proses penanganan pasca panennya (pengolahan dari bentuk gabah menjadi beras), harga yang lebih mahal (dibanding jenis beras lainnya) dan umur tanaman yang lebih lama.

GPO Nyi Sri merupakan salah satu gabungan petani yang ada di Kabupaten Cianjur yang sebagian anggotanya membudidayakan Padi Pandanwangi organik. Gabungan Petani Organik (GPO) Nyi- Sri telah dikukuhkan melalui SK Bupati No. 146 Tahun 2011 pada Tanggal 11 Juli 2011. Saat ini anggotanya telah mencapai seratus orang dan telah tersebar di empat belas kecamatan. Tiap anggotanya memiliki keinginan mencoba sesuatu yang dapat meningkatkan hasil pertaniannnya. Petani mempunyai pilihan tentang keputusannya untuk menanam padi dengan teknik dan inovasi yang dapat meningkatkan hasil produksi budidaya. Budidaya Padi Pandanwangi dengan metode budidaya organik menimbulkan persepsi yang berbeda-beda sehingga tidak semua petani menerapkan. Terkait dengan hal tersebut, perlu dilakukan penelitian tentang persepsi petani tentang inovasi budidaya Padi Pandanwangi organik di GPO Nyi Sri Kecamatan Cianjur Kabupaten Cianjur. 
Berdasarkan pemaparan diatas, tujuan penelitian untuk :

1. Mengetahui karakteristik petani Padi Pandanwangi organik di GPO Nyi Sri Kecamatan Cianjur Kabupaten Cianjur.

2. Mengetahui persepsi petani tentang inovasi budidaya Padi Pandanwangi organik di GPO Nyi Sri Kecamatan Cianjur Kabupaten Cianjur.

3. Mengetahui hubungan antara karakteristik petani dengan persepsi petani tentang inovasi budidaya Padi Pandanwangi organik di GPO Nyi Sri Kecamatan Cianjur Kabupaten Cianjur.

\section{METODE PENELITIAN}

Penelitian ini dilaksanakan di Gabungan Petani Organik (GPO) Kecamatan Cianjur Kabupaten Cianjur. Adapun waktu pelaksanaannya dimulai Bulan Juni sampai Juli 2018.

Populasi berkaitan dengan seluruh kelompok orang, peristiwa atau benda yang menjadi pusat perhatian penelitian untuk diteliti (Cooper, 2003). Dengan kata lain, populasi adalah wilayah generalisasi yang terdiri dari: objek atau subjek yang mempunyai kualitas dan karakteristik tertentu ysng ditetapkan oleh peneliti untuk dipelajari kemudian ditarik kesimpulannya (Kurniawan, 2012). Dari pengertian diatas dapat ditarik kesimpulan, bahwa populasi dalam penelitian ini adalah petani Padi Pandanwangi yang tergabung dalam Gabungan Petani Organik (GPO) Kecamatan Cianjur.

Responden dalam penelitian ini sebanyak 30 orang anggota serta pengurus Gabungan Petani Organik kecamatan Cianjur yang pernah melakukan budidaya Padi Pandanwangi organik. Teknik penentuan responden yaitu dengan sampling purpose.
Untuk memperoleh informasi sesuai tujuan penelitian, dilakukan pengumpulan data. Data dikumpulkan melalui metode :

\section{Wawancara}

Pengumpulan inforrmasi langsung dari sumbernya, melalui komunikasi verbal disebut wawancara (Nasution, 2003). Metode ini digunakan untuk mengetahui hal-hal dari responden secara lebih mendalam, sehingga jumlah responden sedikit.

\section{Observasi}

Untuk mendapatkan data tambahan, pelangkap data wawancara dilakukan observasi/pengamatan. Subjek, perilaku subjek, interaksi subjek dan hal hal lain yang relevan menjadi bahan pengamatan.

\section{Angket (Questionnaire)}

Suatu teknik atau cara pengumpulan data secara tidak langsung disebut angket atau kuesioner. Angket atau kuesiner berisi sejumlah pertanyaan yang harus dijawab responden. Dengan kata lain, angket (questionnaire) merupakan daftar pertanyaan lengkap mengenai banyak hal yang diperlukan oleh peneliti untuk mendapatkan jawaban atas pertanyaan penelitian.

\section{Dokumentasi}

Menurut Sugiyono (2013) catatan peristiwa yang lalu disebut dokumentasi. Tulisan, gambar ataupun karya merupakan bentuk dokumentasi. Ini dilakukan untuk memperoleh data dari tempat penelitian.

Metode penelitian kuantitatif dan kualitatif digunakan dalam penelitian ini. Setiap fenomena social dalam komponen masalah diukur dalam penelitian ini. Proses pengukuran menjadi hal sentral dalam penelitian ini. Variabel Penelitian berupa: 
Tabel 1 : Variabel Penelitian.

\begin{tabular}{|c|c|c|c|c|}
\hline Konsep & Variabel & Indikator & $\begin{array}{l}\text { Sumber } \\
\text { Data }\end{array}$ & Analisis \\
\hline \multirow{6}{*}{$\begin{array}{l}\text { Karakteristik } \\
\text { Petani } \\
\text { (Soekartawi, } \\
\text { 1988) }\end{array}$} & Umur & Umur Petani & Primer & Deskriptif \\
\hline & $\begin{array}{l}\text { Tingkat } \\
\text { Pendidikan }\end{array}$ & Pendidikan yang ditempuh petani & Primer & Deskriptif \\
\hline & $\begin{array}{l}\text { Tingkat } \\
\text { Pendapatan }\end{array}$ & $\begin{array}{l}\text { Hasil dari penerimaan dikurang } \\
\text { biaya produksi usahatani padi } \\
\text { pandanwangi organik pertahun (Rp.) }\end{array}$ & Primer & Deskriptif \\
\hline & $\begin{array}{l}\text { Status Penguasaan } \\
\text { Lahan }\end{array}$ & $\begin{array}{l}\text { Status lahan milik sendiri, sewa } \\
\text { ataupun bagi hasil }\end{array}$ & Primer & Deskriptif \\
\hline & Luas lahan & $\begin{array}{l}\text { Luas lahan yang digarap dan } \\
\text { diusahakan petani. }\end{array}$ & Primer & Deskriptif \\
\hline & $\begin{array}{l}\text { Pengalaman } \\
\text { Usahatani }\end{array}$ & $\begin{array}{l}\text { Pengalaman Petani dalam budidaya } \\
\text { Padi Pandanwangi organik }\end{array}$ & Primer & Deskriptif \\
\hline \multirow{5}{*}{$\begin{array}{l}\text { Persepsi Petani } \\
\text { Tentang } \\
\text { Karakteristik } \\
\text { Inovasi } \\
\text { Teknologi } \\
\text { (Van Den Ban } \\
\text { dan Hawkins, } \\
\text { 2003) }\end{array}$} & $\begin{array}{l}\text { Keuntungan } \\
\text { relatif }\end{array}$ & $\begin{array}{l}\text { Keuntungan yang diperoleh Petani } \\
\text { selama budidaya (Rp) }\end{array}$ & Primer & Deskriptif \\
\hline & $\begin{array}{l}\text { Tingkat } \\
\text { kesesuaian }\end{array}$ & $\begin{array}{l}\text { Inovasi tersebut sesuai dengan } \\
\text { kebutuhan petani }\end{array}$ & Primer & Deskriptif \\
\hline & Tingkat kerumitan & Tingkat kerumitan dalam budidaya & Primer & Deskriptif \\
\hline & $\begin{array}{l}\text { Tingkat } \\
\text { kemudahan untuk } \\
\text { dicoba }\end{array}$ & Tingkat kemudahan dalam budidaya & Primer & Deskriptif \\
\hline & Mudah diamati & $\begin{array}{l}\text { Dalam proses budidaya dimulai dari } \\
\text { persiapan lahan sampai pemanenan }\end{array}$ & Primer & Deskriptif \\
\hline
\end{tabular}

Jenis Data dalam penelitian ini berupa :

1. Data Primer

Data primer adalah data yang diperoleh langsung dari jawaban responden melalui kuesioner. Data ini diperoleh langsung dari objek penelitian (petani responden) dengan cara wawancara berdasarkan daftar pertanyaan (kuisioner) yang telah disiapkan. Data meliputi : identitas responden, persepsi petani tentang budidaya Padi Pandanwangi organik.

\section{Data Sekunder}

Data sekunder adalah sumber data penelitian yang diperoleh secara tidak langsung melainkan melalui media perantara. Data sekunder diperoleh dari GPO Kecamatan Cianjur yang dapat dilihat dokumentasi GPO, buku-buku referensi dan informasi lain yang berhubungan dengan penelitian.

Data dalam penelitian ini dianalisis deskriptif. Menurut Sugiyono (2011), analisis deskriptif adalah analisis yang mendeskripsikan atau memberikan gambaran terhadap objek yang akan diteliti melalui data sampel atau populasi sebagaimana adanya, tanpa membuat kesimpulan yang berlaku untuk umum. Untuk menggambarkan karakteristik petani yang meliputi : umur, pengalaman, pendidikan, tingkat pendapatan, status dan luas lahan dilakukan analisis deskriptif.

Hubungan antara karakteristik Petani dengan Persepsi Petani tentang inovasi budidaya Padi Pandanwangi Organik dianalisis dengan menggunakan rumus Rank Spearman:

$$
\mathrm{rs}=1-\frac{6 \sum d i^{2}}{N^{3}-N}
$$

Keterangan:

Rs : Koefisien korelasi rank spearman

Di : Selisih ranking variable

$\mathrm{N}$ : Banyaknya sampel

Koefisien korelasi merupakan indeks atau bilangan yang digunakan untuk mengukur keeratan (kuat, lemah, atau tidak ada) hubungan antar variabel. Koefisien korelasi memiliki nilai antara -1 dan $+1(-1 \leq \mathrm{KK} \leq+1)$ (Hasan, 2001). 
1. Jika KK bernilai positif maka variabelvariabel berkorelasi positif. Semakin dekat nilai KK ke +1 semakin kuat korelasinya, demikian sebaliknya.

2. Jika KK bernilai negatif maka variabelvariabel berkorelasi negatif. Semakin dekat nilai KK ke -1 semakin kuat korelasinya, demikian sebaliknya.

3. Jika KK bernilai 0 maka variabelvariabel tidak menunjukkan korelasi.
4. Jika KK bernilai +1 atau -1 maka variabel-variabel menujukkan korelasi positif atau negatif yang sempurna.

Hasan (2001) menyatakan nilai nilai dari koefisien korelasi sebagai patokan ntuk menentukan keeratan hubungan atau korelasi antar variabel tersebut. Patokan nilai - nilai koefisien korelasi adalah sebagai berikut :

Tabel 2. Patokan nilai-nilai koefisien korelasi

\begin{tabular}{ccl}
\hline No & Indeks Penilaian & \multicolumn{1}{c}{ Kriteria } \\
\hline 1 & 0 & Tidak ada korelasi \\
2 & $0,01-0,20$ & Korelasi sangat rendah \\
3 & $0,21-0,40$ & Korelasi rendah/ lemah tapi pasti \\
4 & $0,41-0,60$ & Korelasi yang cukup \\
5 & $0,61-0,80$ & Korelasi yang tinggi \\
6 & $0,81-1,00$ & Korelasi yang sangat tinggi \\
\hline
\end{tabular}

\section{HASIL DAN PEMBAHASAN}

\section{Gambaran Umum Gabungan Petani Organik (GPO) Nyi-Sri Kecamatan Cianjur}

Ide pembentukan GPO Nyi Sri berasal dari petani- petani yang mendapat pelatihan System Of Rice Intensification (SRI). Mereka berasal dari kecamatan : Cianjur, Cibeber, Karangtengah, Cikalongkulon, Sukaluyu, Bojongpicung, Ciranjang, Warungkondang dan Cilaku. Pada Tanggal 27 Juli 2009 dibentuklah GPO Nyi Sri yang merupakan wadah bersama untuk menghimpun aspirasi maupun aktivitas petani yang sudah melaksanakan dan mengembangkan inovasi mengenai organik yang ada di Wilayah Kabupaten Cianjur.

Hampir disemua kecamatan terbentuk GPO Nyi Sri. Namun hanya GPO Kecamatan Cianjur yang menjadi tempat penelitian.

\section{Karakteristik Responden}

Responden dalam penelitian berjumlah 30 orang yang berasal dari 3 desa yaitu Desa Bojongherang, Babakan Karet dan Mekarsari yang berada di Kecamatan Cianjur.

\section{Jenis Kelamin}

Karakteristik responden berdasarkan jenis kelamin dalam penelitian ini adalah sebagai berikut:

Tabel 3. Karakteristik Responden Berdasarkan Jenis Kelamin.

\begin{tabular}{clcc}
\hline No & Jenis kelamin & Jumlah (Orang) & Persentase (\%) \\
\hline 1 & Laki-Laki & 28 & 93,33 \\
2 & Perempuan & 2 & 6,67 \\
\hline & Jumlah & $\mathbf{3 0}$ & $\mathbf{1 0 0 , 0 0}$
\end{tabular}

Sumber: data primer (olaban), 2018.

Berdasarkan pada tabel 3, dapat diketahui bahwa mayoritas responden berjenis laki-laki, hal ini dikarenakan lakilaki merupakan kepala keluarga dan bertanggung jawab dalam perekonomian keluarga.

\section{Umur Responden}

Berdasarkan usia, struktur peduduk dibagi dalam tiga kelompok yakni : belum produktif, produktif dan tidak produktif (Samadi , 2006). Belum produktif atau usia muda berumur $0-14$ tahun, usia produktif/dewasa berumur 15 - 64 tahun dan usia tua / tidak produktif jika 
berumur lebih dari 64 tahun. Umur

responden dapat dilihat dalam table 4.

Tabel 4. Karakteristik Responden Berdasarkan Umur.

\begin{tabular}{cccc}
\hline No & Kriteria (Tahun) & Jumlah (Orang) & Persentase (\%) \\
\hline 1 & $<14$ Tahun & - & - \\
2 & 15 - 64 Tahun & 22 & 73,33 \\
3 & $>65$ Tahun & 8 & 26,67 \\
\hline \multicolumn{2}{l}{ Sumber : data primer (olahan), 2018. } & $\mathbf{3 0}$ & $\mathbf{1 0 0 , 0 0}$ \\
\hline
\end{tabular}

Dari tabel di atas mayoritas $(73,3$ $\%$ ) umur responden berada dalam kisaran 15 - 64 tahun. Jika dikelompokkan dalam kategori umur produktif dan non produktif, maka sebagian besar berada pada umur produktif.

\section{Tingkat Pendidikan}

Pendidikan formal adalah tingkat pendidikan yang ditamatkan responden pada lembaga pendidikan formal atau bangku sekolah. Menurut Anggraini
(2011) tingkat pendidikan seseorang akan mempengaruhi cara berpikir, penerimaan suatu informasi, maupun penilaian terhadap suatu masalah yang terjadi.

$$
\text { Robbins (2003) menyatakan }
$$
semakin tinggi tingkat pendidikan semakin luas wawasan seseorang. Wawasan yang luas membantu seseorang untuk tanggap dalam menerima objek baru. Tingkat pendidikan responden dapat dilihat dalam tabel 5 .

Tabel 5 Karakteristik Responden Berdasarkan Tingkat Pendidikan.

\begin{tabular}{clcc}
\hline No & \multicolumn{1}{c}{ Kriteria } & Jumlah (Orang) & Persentase (\%) \\
\hline 1 & Tidak Tamat SD & 4 & 13,34 \\
2 & SD & 17 & 56,66 \\
3 & SMP & 5 & 16,66 \\
4 & SMA/SMK & 4 & 13,34 \\
5 & Perguruan Tinggi & - & - \\
\hline & Jumlah & $\mathbf{3 0}$ & $\mathbf{1 0 0 , 0 0}$ \\
\hline
\end{tabular}

Sumber: data primer (olahan), 2018.

Dari table d iatas, mayoritas adalah tamatan Sekolah Dasar (SD) yaitu sebanyak 17 orang atau (56,6\%). Sedangkan tingkat pendidikan dengan jumlah responden yang paling sedikit adalah pada tingkat tidak tamat SD dan SMA yang masing-masing berjumlah 4 orang atau $(13,4 \%)$. Karena tingkat pendidikan formal yang rendah, sebaiknya disertai dengan pendidikan non formal seperti penyuluhan guna memberikan pengetahuan, ide dan pengalaman baru khususnya dibidang pertanian yang dapat menunjang pengetahuan yang tidak didapatkan di sekolah formal.

\section{Luas Lahan}

Berdasarkan luas lahan garapan, petani digolongkan kedalam 3 (tiga) kategori, yaitu :

1) Petani gurem (sempit) jika luas lahan garapan $<0,5$ hektar.

2) Petani menengah jika luas lahan garapan 0,5-1 hektar.

3) Petani kuat jika lahan garapan $>1$ hektar.

Responden berdasarkan luas lahan yang dikelolanya dapat dilihat pada tabel 6 . 
Tabel 6. Karakteristik Responden Berdasarkan Luas Lahan.

\begin{tabular}{clcc}
\hline No & \multicolumn{1}{c}{ Luas Lahan } & Jumlah (Orang) & Persentase (\%) \\
\hline 1 & $<0,5$ ha & 27 & 90,00 \\
2 & $0,5-1$ ha & 3 & 10,00 \\
3 & $>1$ ha & - & - \\
\hline & Jumlah & $\mathbf{3 0}$ & $\mathbf{1 0 0 , 0 0}$ \\
\hline
\end{tabular}

Sumber : data primer (olahan), 2018.

Berdasarkan tabel diatas diketahui bahwa mayoritas petani organik di GPO Nyi Sri Kecamatan Cianjur memiliki lahan $<0,5$ ha atau $(90 \%)$ yang mana termasuk kedalam golongan petani gurem. Menyempitnya lahan pertanian disebabkan beberapa faktor diantaranya : pembangunan rumah sakit dan perumahan, sehingga setiap tahun terjadi penyempitan lahan pertanian khususnya lahan padi termasuk Padi Pandanwangi organik.

\section{Status Penguasaan Lahan}

Status lahan garapan merupakan status lahan kepemilikan pada masingmasing petani responden. Status tersebut ialah milik pribadi, sewa ataupun bagi hasil. Status kepemilikan lahan merupakan hal yang penting, karena status kepemilikan lahan diharapkan mendorong petani dalam mencurahkan segala upaya dan daya dalam lahan garapannya dengan memilih pola penanaman yang berkelanjutan. Status lahan milik sendiri mendorong perasaan bebas dalam menerapkan teknologi baru demi keberlanjutan usahatani yang lebih baik. Persentase responden berdasarkan status penguasaan lahan tersaji dalam tabel berikut :

Tabel 7. Karakteristik Responden Berdasarkan Status Penguasaan lahan.

\begin{tabular}{|c|c|c|c|c|}
\hline No & Status Penguasaan & Lahan & Jumlah (Orang) & Persentase $(\%)$ \\
\hline 1 & Milik Sendiri & & 18 & 60,00 \\
\hline 2 & Sewa & & 4 & 13,33 \\
\hline 3 & Bagi Hasil & & 8 & 26,67 \\
\hline & Jumlah & & 30 & 100,00 \\
\hline
\end{tabular}

Sumber: data primer (olahan), 2018.

Berdasarkan tabel diatas dapat diketahui bahwa responden petani Padi Pandanwangi organik sebanyak 18 orang atau $(60 \%)$ merupakan pemilik dari lahan usahataninya. Status penguasaan lahan memiliki pengaruh terhadap penerapan inovasi, petani yang memiliki lahan sendiri lebih berpengaruh dalam penerapan teknologi, hal itu dikarenakan wewenang mereka dalam lahan tersebut lebih tinggi dibandingkan dengan status lahan yang lain seperti bagi hasil dan sewa.

\section{Pengalaman Usahatani}

Pengalaman merupakan suatu proses sikap, perilaku, serta kemampuan petani dalam menanggapi objek tertentu, pengalaman petani yang dimaksud dalam penelitian ini adalah lamanya petani dalam mengusahakan lahan sawahnya untuk tanaman padi. Salah satu faktor yang mempengaruhi kemampuan petani dalam melakukan usahatani adalah pengalaman yang dimilikinya. Pengalaman usahatani adalah lamanya seseorang telah menjadi petani/bekerja di bidang pertanian. Semakin banyak pengalaman yang dimiliki petani dalam berusahatani, maka petani akan semakin terampil dalam pengelolaan usahatani, pengolahan pasca panen serta dalam memasarkan hasil usahataninya.

Untuk mengetahui karakteristik responden berdasarkan pengalaman usahatani disajikan pada tabel beriku : 
Tabel 8. Karakteristik Responden Berdasarkan Pengalaman Usahatani.

\begin{tabular}{|c|c|c|c|}
\hline No & Pengalaman Usahatani (Tahun) & Jumlah (Orang) & Persentase $(\%)$ \\
\hline 1 & $<1$ Tahun & ( & - \\
\hline 2 & $1-5$ Tahun & - & - \\
\hline 3 & $6-10$ Tahun & 5 & 16,66 \\
\hline 4 & $11-15$ Tahun & 4 & 13,34 \\
\hline \multirow[t]{2}{*}{5} & $>15$ tahun & 21 & 70,00 \\
\hline & Jumlah & 30 & 100,00 \\
\hline
\end{tabular}

Sumber: data primer (olaban), 2018.

Berdasarkan tabel 8 dapat diketahui bahwa pengalaman petani dalam berusahatani di daerah penelitian sudah lama dalam usaha pertanian. Mayoritas mempunyai pengalaman usahatani lebih dari 15 tahun. Sekitar 20 tahun yang lalu sudah banyak petani yang membudidayakan, dengan cara konvensional dan memakai pupuk kimia serta pestisida. Padi Pandanwangi baru sekitar 5 sampai 7 tahun an dibudidayakan dengan sistem organik. Hal ini karena adanya kesadaran petani di Kecamatan Cianjur akan bahayanya pupuk kimia untuk kesehatan dan juga kesuburan tanah mereka. Dengan bergabungnya petani Kecamatan Cianjur dalam Gabungan Petani Organik semakin menambah ilmu serta pengalaman dalam budidaya Padi Pandanwangi secara organik. Petani berpendapat bahwa organik dapat melakukan pembenahan tanah yaitu memeberikan makanan untuk mikroba dengan memberikan pupuk organik agar hidup dalam tanah yang selanjutnya dapat menyuburkan tanah, juga adanya kemitraan petani dengan pengusaha seperti PT. Wahana Inti dalam memproduksi produk organik menumbuhkan semangat dan inisisatif petani untuk membudidayakan Padi Pandanwangi secara organik.

\section{Persepsi Petani Tentang Inovasi Budidaya Padi Pandanwangi Organik}

Rakhmat (2003) mengartikan persepsi sebagai pengalaman belajar tentang objek, peristiwa, atau hubunganhubungan yang diperoleh dengan menyimpulkan informasi dan menafsirkan pesan. Persepsi juga merupakan suatu bentuk komunikasi intrapersonal, yaitu komunikasi yang terjadi dalam diri seseorang. Oleh karena itu, persepsi akan mempengaruhi seseorang dalam berpikir, bertindak, serta berkomunikasi dengan pihak lain.

Menurut Van den Ban dan Hawkins (2003), persepsi petani tentang karakteristik inovasi teknologi meliputi keunggulan relatif (relative advantage), tingkat kesesuaian inovasi (compability), tingkat kerumitan (complexity), dapat di coba (triability) dan dapat diamati (observability). Dalam penelitian ini, persepsi petani tentang inovasi budidaya Padi Pandanwangi organik mengacu pada pendapat Van den Ban dan Hawkins (2003). Untuk lebih jelasnya mengenai persepsi petani tentang inovasi budidaya Padi Pandanwangi organik dapat dilihat pada tabel 9 . 
Tabel 9. Persepsi Petani Tentang Inovasi Budidaya Padi Pandanwangi di GPO Kecamatan Cianjur.

\begin{tabular}{clcc}
\hline No & \multicolumn{1}{c}{ Variabel } & Rata- Rata Skor & Kategori \\
\hline 1 & Keuntungan Relatif & 2,79 & Netral \\
2 & Tingkat Kesesuaian Inovasi & 3,48 & Setuju \\
3 & Tingkat Kerumitan Inovasi & 3,47 & Setuju \\
4 & Dapat Diuji coba & 3,89 & Setuju \\
5 & Dapat Diamati & 3,99 & Setuju \\
\hline \multicolumn{2}{r}{ Rata-rata } & $\mathbf{3 , 5 2}$ & Setuju \\
\hline
\end{tabular}

Sumber : data primer (olahan), 2018.

Keterangan: 1,00 - 1,80 (Sangat Tidak Setuju), 1,81 - 2,60 (Tidak Setuju) 2,61 - 3,40 (Netral), 3,41 - 4,20 (Setuju), 4,21 - 5,00 (Sangat Setuju)

Berdasarkan tabel di atas, skor terkecil yaitu 2,79 mengenai keuntungan relatif dan skor terbesar yaitu 3,99 pada tingkat dapat diamati. Skor total rata-rata persepsi petani tentang inovasi budidaya Padi Pandanwangi organik adalah 3,52. Skor ini menunjukkan bahwa responden setuju inovasi budidaya Padi Pandanwangi organik. Rincian dari persepsi petani tentang karakter inovasi teknologi terdapat dalam uraian berikut :

\section{Persepsi Petani Terhadap Keuntungan relatif}

Keuntungan relatif suatu inovasi adalah tingkatan dimana suatu ide dapat dianggap suatu hal yang baik dari pada ide-ide yang ada sebelumnya, dan secara ekonomis menguntungkan. Keuntungan relatif dibedakan menjadi lima macam, yaitu 1) manfaat biaya adalah keuntungan yang diperoleh dari inovasi karena adanya penghematan biaya, 2) manfaat waktu adalah keuntungan yang diperoleh dari inovasi karena adanya penghematan waktu, 3) kenaikan pendapatan adalah keuntungan yang diperoleh dari inovasi karena adanya kenaikan pendapatan, 4) keefektifan tenaga kerja adalah keuntungan yang diperoleh dari inovasi karena adanya penghematan tenaga kerja, 5) Perbandingan harga adalah keuntungan yang diperoleh dari inovasi karena adanya keuntungan yang lebih dibandingkan dengan metode sebelumnya. Persepsi akan positif apabila inovasi atau suatu metode memberikan keuntungan yang lebih baik dibanding teknologi yang ada sebelumnya.
Rata-rata skor mengenai manfaat biaya sebesar 2,33. Nilai tersebut mempunyai arti bahwa responden menyatakan tidak setuju bahwa inovasi budidaya Padi Pandanwangi organik mempunyai manfaat biaya bagi petani. Menurut petani biaya dalam budidaya Padi Pandanwangi organik lebih besar dari budidaya padi biasa, biaya-biaya tersebut di antaranya biaya pengangkutan bahan-bahan untuk dijadikan kompos dan pupuk alami yang jauh dari rumah.

Rata-rata skor mengenai manfaat waktu untuk petani Padi Pandanwangi organik adalah 2,00. Nilai tersebut menunjukkan bahwa responden tidak setuju bahwa dalam budidaya Padi Pandanwangi organik memerlukan waktu yang lebih sedikit dibandingkan dengan padi biasa. Menurut petani, Padi Pandanwangi organik memerlukan waktu yang lama dalam budidaya yakni 1 musim tanam memerlukan waktu 6 bulan dibandingkan dengan padi pada umumnya yang hanya memerlukan waktu tanam 4 bulan dalam 1 musim tanam.

Rata-rata skor mengenai kenaikan pendapatan adalah 2,26. Hal ini menunjukkan bahwa responden tidak setuju bahwa budidaya Padi Pandanwangi organik mempunyai pendapatan yang tinggi. Petani menyatakan bahwa hasil panen Padi Pandanwangi organik lebih sedikit dibanding dengan padi biasa dan harga Padi Pandanwangi relatif lebih mahal, namun biaya usahatani Padi Pandanwangi organik lebih banyak sehingga petani tidak merasakan kenaikan pendapatan. 
Rata-rata skor mengenai keefektifan tenaga kerja menghasilkan skor 2,93. Hal ini dapat menunjukkan bahwa responden menyatakan netral bahwa tenaga kerja yang dibutuhkan dalam budidaya Padi Pandanwangi organik lebih sedikit. Hal ini disebabkan karena jarak dari rumah ke sawah jauh sampai dekat, sehingga apabila jarak dari rumah ke sawah jauh, maka pengangkutan pupuk kandang, kompos, dll harus dibantu dengan tenaga kerja lain.

Rata-rata skor mengenai perbandingan harga menghasilkan skor sebesar 4,43. Tentu hal ini dapat menunjukkan bahwa responden Padi Pandanwangi organik Kecamatan Cianjur menyatakan sangat setuju bahwa harga Padi Pandanwangi organik lebih mahal dibandingkan dengan padi varietas lain.

\section{Persepsi Petani Terhadap Tingkat Kesesuaian}

Hanafi dalam Alisa (2007) mengatakan bahwa tingkat kesesuaian suatu inovasi adalah sejauh mana inovasi dianggap konsisten dengan nilai-nilai yang ada, pengalaman masa lalu dan kebutuhan penerima. Kesesuaian suatu inovasi dibedakan menjadi empat macam, yaitu 1) kondisi lingkungan adalah keadaan tempat tinggal petani, 2) Kebiasaan petani adalah tata cara budidaya yang sudah biasa dilakukan petani, 3) kebutuhan petani adalah keinginan yang cocok dengan kondisi petani, 4) kelestarian lingkungan adalah persepsi petani mengenai dampak metode yang dilakukan terhadap alam.

Rata-rata skor untuk tingkat kesesuaian inovasi dalam budidaya Padi Pandanwangi organik terhadap kondisi lingkungan adalah 3,96. Responden menyatakan setuju bahwa kondisi lingkungan sesuai untuk budidaya Padi Pandanwangi organik. Dikarenakan Padi Pandanwangi hanya dapat tumbuh optimal di Cianjur, bahan-bahan untuk membuat kompos dan pestisida alami banyak ditemukan di sekitar lahan atau rumah, didukung oleh metode yang digunakan sangat ramah terhadap lingkungan sehingga dapat membuat tanah subur dan menjaga ekosistem.

Rata-rata skor mengenai kebiasaan petani adalah 2,53. Hal ini menunjukkan bahwa responden tidak setuju bahwa budidaya Padi Pandanwangi organik dapat merubah kebiasaan petani dari metode sebelumnya. Menurut petani, kendalakendala yang dihadapi oleh petani selama budidaya Padi Pandanwangi organik seperti lamanya waktu penanaman, hasil produksinya masih sedikit dan penghasilan dari budidaya Padi Pandanwangi organik relatif sedikit dibanding dengan padi biasanya sehingga banyak petani yang beralih budidaya padi varietas lain dengan metode sebelumnya.

Rata-rata skor mengenai kebutuhan petani adalah 3,33. Hal ini menunjukkan bahwa responden menyatakan netral bahwa budidaya Padi Pandanwangi organik dapat meningkatkan hasil produksi padi yang selanjutnya dapat meningkatkan pendapatan petani.

Rata-rata skor mengenai kelestarian lingkungan adalah 4,13. Hal ini menunjukkan bahwa responden menyatakan setuju budidaya Padi Pandanwangi organik ikut menjaga kelestarian lingkungan, hal ini dikarenakan dalam pelaksanaannya budidaya Padi Pandanwangi organik menggunakan bahan-bahan tanpa kimia seperti pupuk, pestisida nya dibuat dari bahan-bahan alami. Petani Padi Pandanwangi organik berpendapat bahwa dengan sistem organik dapat memperbaiki kesuburan tanah dan menyediakan makanan didalam tanah untuk padi.

\section{Persepsi Petani Terhadap Tingkat Kerumitan}

Rogers dalam Alisa (2007), menyebutkan tingkat kerumitan inovasi adalah kesulitan yang dipersepsi dari inovasi untuk bisa dimengerti atau untuk bisa dilakukan oleh adopters-nya. Tingkat kerumitan inovasi dibedakan menjadi tiga macam, yaitu 1) kemudahan dalam penggunaan, 2) kepraktisan, 3) keterampilan. 
Rata-rata skor mengenai kemudahan dalam penggunaan budidaya Padi Pandanwangi oganik adalah 3,93. Hal ini menunjukkan bahwa responden setuju budidaya Padi Pandanwangi organik dianggap memiliki kemudahan dalam budidaya nya seperti : pemupukan, penyiangan, penanganan hama dan penyakit dan lain-lain.

$$
\text { Rata-rata skor mengenai }
$$

kepraktisan adalah 2,93. Hal ini dapat menunjukkan bahwa persepsi responden netral. Menurut petani dalam budidaya Padi Pandanwangi organik ada kerumitan, berupa keharusan membuat pupuk dan pestisida organik. Rata-rata skor mengenai keterampilan adalah 3,56, angka tersebut menunjukkan responden setuju bahwa membudidayakan Padi Pandanwangi organik membutuhkan keterampilan.

\section{Persepsi Petani Terhadap Dapat Diujicoba \\ Dapat diujicoba dibedakan menjadi} dua macam, yaitu : 1) Pengalaman uji coba, dan 2) Dukungan pemerintah. Skor maksimal persepsi petani tentang budidaya Padi Pandanwangi organik terdapat pada tingkat dukungan pemerintah yang menghasilkan skor 3,93 dan skor terendah pada tidak/pernah nya ujicoba dengan skor sebesar 3,86. Ratarata skor sebesar 3,89 yang artinya responden setuju bahwa budidaya Padi Pandanwangi organik dapat diujicoba.

Rata-rata skor mengenai adanya dukungan pemerintah adalah 3,93. Hal ini menunjukkan bahwa petani setuju dalam budidaya Padi Pandanwangi organik ada dukungan dari pemerintah. Dukungan tersebut diantaranya dukungan berupa bibit, yang disebar rata diberikan kepada petani Gabungan Petani Organik.

\section{Persepsi Petani Terhadap Dapat Diamati}

Tingkat dapat diamati dibedakan kedalam 2 kategori, yaitu : 1) Mudah dilihat, dan 2) Mudah mendapatkan informasi. Rogers dalam Alisa (2007) mengemukakan bahwa tingkat kemudahan suatu inovasi untuk dilihat hasilnya adalah derajat dimana hasil inovasi itu dapat dilihat atau dirasakan oleh penganut yang berpotensi (potential adopter).

Skor terkecil yaitu mudah mendapatkan informasi dengan skor 3,96 dan skor tertinggi pada kemudahan diamati dengan skor 4,03. Rata-rata skor tentang persepsi petani mengenai tingkat dapat diamati yaitu sebesar skor adalah 3,99. Hal ini menunjukkan bahwa responden setuju budidaya Padi Pandanwangi organik mudah untuk diamati.

\section{Hubungan Karakteristik Petani dengan Persepsi Petani Tentang Inovasi Budidaya Padi Pandanwangi Organik}

Penelitian ini mengunakan analisa uji Rank Spearman. Menurut Djarwanto (2009), metode korelasi ini dikemukakan oleh Carl Spearman pada Tahun 1904. Metode ini diperlukan untuk mengukur keeratan hubungan antara dua variabel di mana dua variabel itu tidak mempunyai joint normal distribution dan conditional variance tidak diketahui sama. Korelasi rank dipergunakan apabila pengukuran kuantitatif secara eksak tidak mungkin/sulit dilakukan.

Hasil analisi uji Rank Spearman untuk mengetahui korelasi antara karakteristik petani dengan persepsi petani tentang inovasi budidaya Padi Pandanwangi organik disajikan pada tabel 10. 
Tabel 10. Hubungan Karakteristik Petani dengan Persepsi Petani Tentang Inovasi Budidaya Padi Pandanwangi Organik.

Correlations

\begin{tabular}{|ccc|c|c|}
\hline & & & PERSEPSI & KARAKTERISTIK \\
\hline Spearman's rho & PERSEPSI & Correlation Coefficient & 1.000 & .052 \\
& & Sig. (2-tailed) &. & .783 \\
& & $\mathrm{~N}$ & 30 & 30 \\
\cline { 2 - 5 } & KARAKTERISTI & Correlation Coefficient & .052 & 1.000 \\
$\mathrm{~K}$ & Sig. (2-tailed) & .783 &. \\
& $\mathrm{~N}$ & 30 & 30 \\
\hline
\end{tabular}

Sumber : data primer (olahan), 2018.

Berdasarkan hasil analisis pada tabel 20, nilai korelasi sebesar 0,052 menunjukkan hubungan persepsi dengan karakteristik berkorelasi sangat rendah. Hal ini dikarenakan karakteristik petani tidak mendukung terhadap persepsi, seperti :

a) Umur, mayoritas responden berumur 50 - 64 tahun, sehingga responden merasa sudah tua untuk melakukan usaha Padi Pandanwangi organik.

b) Pendidikan, mayoritas responden berpendidikan sekolah dasar, sehingga mereka merasa rumit dalam melakukan budidaya Padi Pandanwangi organik.

c) Pendapatan responden yang rendah menyulitkan responden untuk budidaya Padi Pandanwangi organik, karena budidaya Padi Pandanwangi memerlukan biaya yang lebih besar.

d) Luas lahan yang sedikit dan status penguasaan lahan milik sendiri, mendorong mereka untuk menghasilkan penghasilan yang lebih dengan cara membudidayakan padi VUN (Varietas Unggul Nasional).

\section{KESIMPULAN}

1. Petani Padi Pandanwangi organik di Gabungan Petani Organik Kecamatan Cianjur sebagian besar berada pada kelompok usia produktif, menempuh pendidikan di tingkat pendidikan dasar, menggarap lahan milik sendiri dengan luas lahan $<0,5$ ha dan memiliki pengalaman yang cukup dalam membudidayakan Padi Pandanwangi organik.

2. Persepsi petani tentang inovasi budidaya Padi Pandanwangi organik termasuk dalam kategori setuju dengan skor 3,52. Artinya, responden setuju tentang inovasi Padi Pandanwangi organik.

3. Hubungan antara karakteristik petani dengan persepsi petani tentang inovasi budidaya Padi Pandanwangi organik menunjukkan korelasi yang sangat rendah dengan nilai sebesar 0,052. Hal ini dikarenakan karakteristik petani tidak mendukung terhadap persepsi seperti: umur, pendidikan, pendapatan, luas lahan dan status penguasaan lahan.

\section{DAFTAR PUSTAKA}

Alisa, I. 2007. Persepsi Petani Terhadap Inovasi Untuk Menggunakan Pupuk Kompos Kotoran Ternak Produksi P4S Bumi Lestari Sragen. Skripsi. Institut Pertanian Bogor. Bogor.

Anggraini, M.S. 2011. Persepsi Petani Terhadap Pengembangan Komoditas Garut (Maranta Aurindinacea L) di Kecamatan Polokarto Kabupaten Sukoharjo. Skripsi. Universitas Sebelas Maret. Surakarta.

Budianta, E. 2004. Organik Terpadu. Yayasan Sosial Tani Membangun. Jakarta. 
Cooper, et all. 2003. Business Research Methods. New York : Mc Grow. Hill Higher Education.

Damardjati, DS. 2005. Kebijakan Operasional Pemerintah Dalam Pengembangan Pertanian Organik Di Indonesia. Materi workshop dan Kongres Nasional II MAPORINA, 21 Desember 2005, Jakarta.

Djarwanto, PS. 2009. Statistic Nonparametrik. BPFE. Yogyakarta.

Hasan, M. I. 2001. Statistika 1 dan Statistika 2. Edisi kedua. Jakarta : Bumi Aksara.

Hidayat AS, Lesmana T. 2011. The Development Of Organic Rice Farming In Indonesia. RIEBS. 2 (1): 1-14).

Kurniawan, B. 2012. Metodologi Penelitian. Jelajah Nusa. Tangerang.

Mayrowani, H., dkk. 2010. Analisa Usahatani Padi Organik Di Kabupaten Sragen. Laporan Penelitian. JIRCAS.

Nasution, S. 2003. Metode Research : Penelitian Ilmiah. Bumi Aksara. Jakarta.
Rakhmat, J. 2003. Psikologi Komunikasi. PT. Rosdakarya Group. Bandung.

Robbins, S. P. 2003. Perilaku Organisasi. PT Indeks Kelompok Gramedia. Jakarta.

Samadi. 2006. Geografi 2. Yudhistira. Bogor.

Sugiyono. 2011. Statistika Untuk penelitian. Alfabeta. Bandung. 2013. Metode Penelitian Kombinasi (Mixed Methods). Alfabeta. Bandung.

Soekartawi E. 1988. Prinsip Dasar Komunikasi Pertanian. Universitas Indonesia. Jakarta.

Van den Ban, HS. H. 2003. Penyuluhan Pertanian. Yogyakarta : Kanisius. 